\title{
PENGARUH REGULASI DIRI DAN SIKAP PADA MATEMATIKA TERHADAP KEMAMPUAN MEMECAHKAN MASALAH MATEMATIKA
}

\author{
ELFIADI \\ PAUD PPs Universitas Negeri Jakarta \\ Jl. Rawamangun Muka, Jakarta Timur. Email: adyelfiadi@yahoo.co.id
}

\begin{abstract}
Mathematics is a part of cognitive development that need to optimalize towards early childhood students. Mathematics can help the children to think logic, sistematic, and solve the problems in the daily life. Unfortunately, from the research in some of elementary school at Kota Juang Bireuen sub district has found that student's ability to solve about mathematics problem still low especially for third grade students. The purpose of this study is to know the direct effects of self regulation and mathematics attitude towards student's ability to solve mathematics problems. This research use quantitatif asosiatif approach. The method of this research use path analysis survey. In this research there are 95 students from 4 schools that chosen by multistage random sampling technique. Data collection with test and questionairre. The results of the research show that there are positive direct effect of self regulation towards mathematics problem solving ability with score 0.321. There are positive direct effect of mathematics attitude towards mathematics problem solving with score 0.384, and there are positive direct effect of self regulation toward mathematics attitude with score 0.324.The conclusion of this research are: (1) self regulation give direct positive effect towards mathematic problem solving ability, (2) mathematics attitude give positive direct effect towards mathematics problem solving ability, (3) self regulation give positive direct effect towards mathematics attitude.
\end{abstract}

Keywords: Self Regulation, Mathematics Attitude, Mathematics Problem Solving Ability

\begin{abstract}
Abstrak: Pengetahuan tentang matematika merupakan salah satu bagian dari aspek kognitif yang sangat penting untuk dioptimalkan dalam perkembangan anak usia dini. Matematika dapat melatih anak berpikir logis, sistematis, serta sebagai sarana dalam mengasah kemampuan memecahkan masalah dalam kehidupan sehari-hari. Kenyataan yang terjadi di beberapa SD Negeri di kecamatan Kota Juang-Bireuen ditemukan bahwa kemampuan memecahkan masalah matematika siswa kelas III masih rendah. Penelitian ini yang bertujuan untuk mengetahui pengaruh regulasi diri dan sikap siswa pada matematika terhadap kemampuan memecahkan masalah matematika. Selanjutnya, penelitian ini dilakukan dengan menggunakan pendekatan kuantitatif jenis asosiatif melalu metode survai teknik analisis jalur. Pemilihan sampel penelitian menggunakan teknik multistage random sampling dengan total sampel yang terpilih berjumlah 95 siswa dari empat sekolah. Teknik pengumpulan data menggunakan instrumen berbentuk tes dan angket. Hasil penelitian menunjukkan bahwa: (1) terdapat pengaruh langsung positif regulasi diri terhadap kemampuan memecahkan masalah matematika dengan nilai koefisien jalur sebesar 0,321, (2) terdapat pengaruh langsung positif sikap pada matematika terhadap kemampuan memecahkan masalah matematika dengan nilai koefisien jalur sebesar 0,384, dan (3) terdapat pengaruh langsung positif regulasi diri terhadap sikap pada matematika dengan nilai koefisien jalur sebesar 0,324. Berdasarkan hasil penelitian tersebut dapat disimpulkan bahwa: (1) regulasi diri berpengaruh langsung positif terhadap kemampuan memecahkan masalah matematika, (2) sikap pada matematika berpengaruh langsung positif terhadap kemampuan memecahkan masalah matematika, dan (3) regulasi diri berpengaruh langsung positif terhadap sikap pada matematika.
\end{abstract}

Kata Kunci : Regulasi Diri, Sikap pada Matematika, Kemampuan Memecahkan Masalah Matematika. 
Salah satu bidang ilmu yang harus dikuasai anak usia dini (usia 08 tahun) khususnya di jenjang sekolah dasar kelas awal adalah bidang ilmu matematika. Matematika merupakan suatu ilmu pengetahuan sebagai sarana berpikir logis, analitis, sistematis, serta sarana melatih kemampuan memecahkan masalah dalam kehidupan sehari-hari. Oleh karena itu penguasaan tentang konsep-konsep matematika sangat diperlukan sejak dini. Berdasarkan hasil penelitian Trends in International Mathematics and Science Study (TIMSS) yang dilakukan oleh Frederick K. S. Leung (dalam harian okezone, 2013) salah seorang Guru besar dari Universitas Hong Kong menyebutkan bahwa indeks literasi matematika siswa Indonesia sangat rendah. Menurut Leung, penerapan kurikulum matematika di Indonesia belum menekankan pada pemecahan masalah, melainkan hanya pada halhal prosedural. Siswa hanya dilatih menghafal rumus, tetapi kurang menguasai penerapannya dalam pemecahan masalah sehingga saat diberikan soal-soal yang lebih rumit dan bernalar, siswa sangat sulit untuk mengerjakannya. Sehubungan dengan permasalahan ini, berdasarkan hasil wawancara dengan beberapa guru kelas III SDN yang tersebar di kecamatan Kota Juang kabupaten Bireuen-Aceh, penulis menemukan bahwa kemampuan siswa dalam memecahkan masalah matematika masih rendah. Kebanyakan siswa mengalami kesulitan dalam menyelesaikan tugas latihan maupun pekerjaan rumah (PR) yang berbentuk soal-soal cerita dengan kemampuan berpikir dan bernalar.

Salah satu faktor yang dapat mempengaruhi kemampuan memecahkan masalah matematika adalah sikap pada matematika. Menurut Juter (2005:91-110) "students with positive attitudes perform better in solving problems" sikap positif siswa terhadap matematika mempengaruhi kemampuan siswa untuk memecahkan masalah matematika dengan sukses". Faktor lain yang ikut mempengaruhi kemampuan 
Pengaruh Regulasi ...

Elfiadi

memecahkan masalah matematika adalah berkaitan dengan kemampuan mengatur diri. Kemampuan mengatur diri disebut juga dengan istilah regulasi diri (self regulation) mempunyai dampak pada siswa untuk mencapai tujuan pembelajarannya. Zimmerman (dalam Winne 1997:397) mengatakan bahwa "self-regulated learning as constitutive of success in learning, problem solving, transfer, and academic success in general" regulasi diri dalam belajar sebagai dasar kesuksesan belajar, pemecahan masalah dan kesuksesan akademis secara umum. Selain itu, regulasi diri juga merupakan salah satu faktor penting dalam membentuk sikap siswa pada matematika. Hal ini sebagaimana pendapat Boekaerts (dalam Karen 2005:296) bahwa "students with good self regulation achieve higher in school, have a more positive attitude towards learning, show a higher trust in their abilities, and have more efficient learning and motivational strategies" siswa dengan regulasi diri yang baik mencapai lebih tinggi di sekolah, memiliki sikap yang lebih positif terhadap pembelajaran, menunjukkan kepercayaan yang lebih tinggi dalam kemampuan mereka, dan belajar lebih efisien dengan banyak strategi dan motivasi.

Kemampuan

Memecahkan

\section{Masalah Matematika}

Pemecahan

masalah merupakan salah satu jenis kemampuan pengolahan kognitif yang sangat diperlukan dalam proses pembelajaran. Menurut Robbins (2011:86) "ability refers to an individual's capacity to perform the various tasks in job, intellectual abilities are those needed to perform mental activities" kemampuan mengacu pada kapasitas individu untuk melakukan berbagai tugas dalam suatu pekerjaan, kemampuan juga sebagai suatu daya untuk melakukan aktivitas mental yang berupa pembawaan dan hasil latihan.

Berkaitan dengan kemampuan pemecahan masalah, Santrock (2008:368) mengatakan bahwa "pemecahan masalah adalah mencari cara yang tepat untuk mencapai suatu tujuan". Selanjutnya Kaazantzis (2010:81) juga mengatakan bahwa "Problem solving refers to the 
JURNAL PENDIDIKAN USIA DINI

Volume 10 Edisi 1, April 2016

process of discovering solutions to specific problems, whereas solution implementation refers to the process carrying out those solutions in the actual problematic situations" pemecahan masalah mengacu pada proses untuk menemukan solusi dari suatu masalah tertentu, sedangkan pelaksanaan dari solusi tersebut mengacu pada proses menyelesaikan pemecahan yang terdapat dalam suatu situasi yang masih diragukan". Selain itu, menurut Woolfolk (2009:74-75), problem solving (pemecahan masalah) merupakan "menciptakan solusi baru untuk suatu masalah, dengan langkah-langkah pemecahan disingkat menjadi IDEAL; (a) Identification, (b) Define (mendefinisikan) tujuan, (c) Explore (mengeksplorasi), (d) Anticipate (mengantisipasi) hasil dan act (bertindak), (e) Look (menengok) ke belakang learn (mengambil pelajaran).

Selanjutnya berkaitan dengan matematika, menurut NCTM dalam Sandra (2011:30-31), Content and processes for early childhood mathematics include the need for young children to develop understanding in algebraic thinking, geometric logic, data analysis, measurement benchmarks, and number concepts. Konten dan proses matematika untuk anak usia dini termasuk kebutuhan bagi anakanak untuk mengembangkan pemahaman dalam berpikir aljabar, logika geometris, analisis data, tolok ukur pengukuran, dan konsep angka.

Secara umum dapat disimpulkan bahwa kemampuan memecahkan masalah matematika merupakan suatu kemampuan individu untuk menemukan solusi atau pemecahan masalah yang berkaitan dengan materi matematika yang dilakukan melalui suatu proses dan tahapan tertentu.

\section{Regulasi Diri}

Regulasi diri (self regulation) diartikan sebagai proses dimana seseorang dapat mengatur pencapaian dan aksi mereka sendiri. Shonkoff dan Phillips (2006:1) mengatakan "self-regulation as a child's ability to gain control of bodily functions, manage powerful emotions, and maintain focus and attention" regulasi diri sebagai kemampuan seorang anak untuk mendapatkan 
Pengaruh Regulasi ...

Elfiadi

kontrol fungsi tubuh, mengelola

sangat dibutuhkan oleh anak agar emosi kuat, dan mempertahankan fokus dan perhatian. Menurut Esther dan Henk (dalam Baumiester 2013:1) "the term self regulation often refers to the exertion of control the self by the self whice involves altering the way in individual feels, thinks, or behaves in order to persue short or long term interest”. Istilah regulasi diri sering kali mengacu pada penggunaan suatu kontrol diri oleh diri sendiri yang mengakibatkan perubahan pada seseorang dengan melibatkan perasaan, berpikir atau perilaku dalam diri yang diperintahkan dalam jangka pendek maupun jangka panjang. Selanjutnya Menurut Santrock (2006:236), "self regulatory learning the self generation and self monitoring of thoughts, feelings, and behaviors in order to reach a goal" regulasi diri dalam belajar merupakan pembangkitan diri dan pemantauan diri dari pikiran, perasaan, dan perilaku untuk mencapai tujuan.

Regulasi diri bagi seorang anak merupakan hal yang sangat penting dalam melakukan berbagai kegiatan. Pengendalian diri sejak dini memiliki kemampuan dalam mengatur dirinya sendiri serta mampu membuat keputusan sendiri. Menurut Papalia (2009:493), “pengendalian emosional melibatkan usaha untuk mengontrol emosi, perhatian, dan perilaku. Anak-anak dengan pengendalian diri yang rendah cenderung mudah marah atau frustasi ketika diganggu atau dicegah untuk melakukan sesuatu yang mereka ingin lakukan. Sedangkan anak dengan pengendalian diri yang tinggi dapat menahan dorongan untuk menunjukan emosi negatif pada saat yang tidak tepat".

Dari beberapa pendapat di atas disimpulkan bahwa regulasi diri adalah kemampuan siswa untuk mengatur dan mengelola proses belajar, emosi, pikiran, serta mampu mengatur perilakunya sendiri dalam mencapai suatu tujuan dan keberhasilan.

\section{Sikap Pada Matematika}

Sikap dalam bahasa Inggris disebut "attitude". Menurut Ajzen (2005:3) "an attitude is a disposition to respond favorably or unfavorably to an object, person, institution, or 
JURNAL PENDIDIKAN USIA DINI

Volume 10 Edisi 1, April 2016

event" sikap sebagai suatu

mengacu pada tiga komponen yang kecenderungan untuk merespon secara baik atau tidak baik terhadap suatu benda, orang, institusi, atau peristiwa. Pendapat yang sama juga dikemukakan oleh Littlejohn (2001:123), bahwa "an attitude is a predisposition to act in a positive or negative way towards some object" sikap adalah kecenderungan untuk bertindak dengan cara yang positif atau negatif terhadap beberapa objek. Menurut Aiken (1994:230), “An attitude is a learned predispositions to respond positively or negatively to a certain object, situation, institution, or person" As such, it consists of cognitive (knowledge or intellective), affective (emotional and motivational), and performance (behavioral or action) components". Sikap adalah sebuah kecenderungan belajar untuk merespon secara positif atau negatif terhadap suatu objek tertentu, situasi, institusi, atau orang. sikap terdiri dari komponen kognitif (pengetahuan), afektif (emosional dan motivasi), dan kinerja (perilaku atau tindakan).

Selanjutnya menurut Breckler (dalam Carlson 2000:482), kata sikap

berbeda, yaitu: afektif, perilaku, dan kognitif "the word attitude refers to three different components: affective, behavioral, and cognitive.

Dari beberapa pendapat di atas, dapat disistesiskan bahwa sikap merupakan suatu kecenderungan seseorang untuk merespon secara positif atau negatif terhadap objek tertentu, yang meliputi komponen kognitif, afektif dan konatif. Adapun yang menjadi objek disini adalah matematika. Sehingga sikap pada matematika merupakan suatu kecenderungan siswa untuk merespon secara positif atau negatif terhadap matematika, yang meliputikomponen kognitif (kepercayaan siswa pada matematika), afektif (perasaan siswa pada matematika), dan konatif (kecenderungan siswa bertindak pada matematika). Berdasarkan latar belakang dan teori tersebut di atas, maka penelitian ini bertujuan untuk untuk mengetahui; (1) pengaruh langsung regulasi diri terhadap kemampuan memecahkan masalah matematika, (2) pengaruh langsung sikap pada matematika terhadap kemampuan memecahkan masalah 
Pengaruh Regulasi ...

Elfiadi

matematika, dan (3) pengaruh

hubungan antar variabelnya, langsung regulasi diri terhadap sikap pada matematika.

\section{METODE PENELITIAN}

Metodelogi penelitian yang digunakan dalam penelitian ini adalah metode survai dengan teknik analisis jalur (path Analysis). Teknik analisis jalur dipilih dengan pertimbangan kemudian dilanjutkan pengujian pengaruh langsung dari tiap-tiap variabel bebas (eksogen), yaitu regulasi diri $\left(\mathrm{X}_{1}\right)$ dan sikap pada matematika $\left(\mathrm{X}_{2}\right)$ terhadap variabel terikat (endogen) yaitu kemampuan memecahkan masalah matematika $\left(\mathrm{X}_{3}\right)$. Adapun konstelasi penelitian ini adalah sebagai berikut:

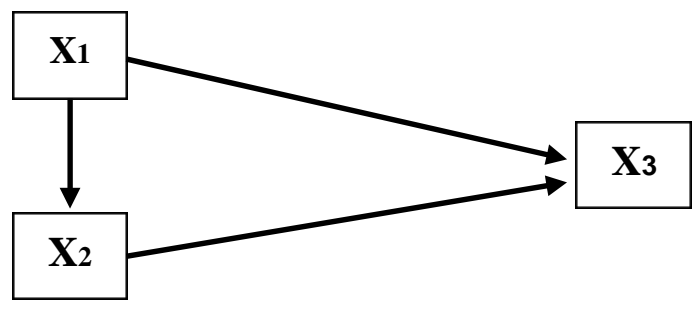

\section{Gambar 1. Konstalasi Penelitian}

Populasi dalam penelitian ini adalah seluruh siswa kelas III Sekolah Dasar Negeri yang terdapat di wilayah Kecamatan Kota Juang kabupaten Bireuen, yang terdiri dari empat sekolah. Yaitu: SDN 3 Bireuen, SDN 4 Bireuen, SDN 5 Bireuen, dan SDN 21 Bireuen. Pemilihan sampel penelitian dengan menggunakan teknik acak sederhana (multistage random sampling) dengan total keseluruhan sampel yang terpilih dari keempat sekolah tersebut berjumlah 95 siswa.

Selain itu, teknik pengumpulan data yang digunakan dalam penelitian ini menggunakan instrumen berbentuk tes dan angket yang memuat seperangkat daftar pernyataan yang dipersiapkan secara khusus. Angket digunakan untuk mendapatkan data tentang variabel eksogen, yaitu regulasi diri $\left(\mathrm{X}_{1}\right)$ dan sikap pada matematika $\left(\mathrm{X}_{2}\right)$, 
JURNAL PENDIDIKAN USIA DINI

Volume 10 Edisi 1, April 2016

sedangkan tes digunakan untuk

menggunakan: uji normalitas, uji mengetahui kemampuan

memecahkan masalah matematika $\left(\mathrm{X}_{3}\right)$ yang merupakan variabel endogen. Berdasarkan hasil uji coba instrumen, variabel regulasi diri diperoleh 14 butir instrumen valid, dengan hasil perhitungan reliabilitas Alpha Cronbach sebesar 0,87. Variabel sikap pada matematika diperoleh 15 butir instrumen valid, dengan hasil perhitungan reliabilitas Alpha Cronbach sebesar 0,80. Selanjutnya variabel kemampuan memecahkan masalah matematika diperoleh 4 butir soal valid, dengan hasil perhitungan reliabilitas Alpha Cronbach sebesar 0,6.

Analisis data dalam penelitian ini menggunakan teknik analisis jalur (path analysis). Analisis jalur merupakan suatu metode yang digunakan pada model kausal yang telah dirumuskan peneliti berdasarkan subtansi keilmuan dan landasan teoritis. Menurut Kadir (2010:172) metode analisis jalur berguna untuk mengecek atau menguji kausalitas yang telah diteorikan. Selanjutnya, untuk uji persyaratan analisis dan uji statistik signifikansi dan uji koefesien regresi, serta pengujian koefisien jalur.

\section{HASIL DAN PEMBAHASAN}

Data-data hasil penelitian yang meliputi data variabel endogen $\mathrm{X}_{3}$ (kemampuan memecahkan masalah matematika) dan variabel eksogen $\mathrm{X}_{1}$ (regulasi diri) serta variabel $\mathrm{X}_{2}$ (sikap pada matematika) kemudian diolah secara statistik ke dalam daftar distribusi frekuensi berdasarkan banyak kelas yang hitung menurut aturan Sturges. Adapun hasil pengolahan ketiga variabel tersebut adalah sebagai berikut:

Kemampuan

Memecahkan

Masalah Matematika

Berdasarkan hasil olahan data secara statistik ke dalam daftar distribusi frekuensi, dapat di tafsirkan bahwa skor kemampuan memecahkan masalah matematika tersebar pada beberapa kelompok kelas interval, yaitu skor dengan persentase tertinggi terdapat pada kelas interval 22-33 sebesar $25 \%$. Sedangkan skor dengan persentase terendah terdapat pada kelas interval 
Pengaruh Regulasi . . .

Elfiadi

82-93 dan 94-105 dengan persentase sebesar 3\%. Secara umum dapat dikatakan bahwa skor kemampuan memecahkan masalah matematika tersebut kebanyakan berkumpul pada nilai kurang dari 58.

\section{Regulasi Diri}

Berdasarkan hasil olahan data secara statistik ke dalam daftar distribusi frekuensi, dapat ditafsirkan bahwa skor regulasi diri tersebar pada beberapa kelompok kelas interval, yaitu skor dengan persentase tertinggi terdapat pada kelas interval 38-40 sebesar 32\%. Sedangkan skor dengan persentase terendah terdapat pada kelas interval 23-25 dengan persentase sebesar 1\%. Secara umum skor dari variabel regulasi diri hampir sebagian besar berkumpul pada nilai lebih dari 34.

\section{Sikap Pada Matematika}

Berdasarkan hasil olahan data secara statistik ke dalam daftar distribusi frekuensi, dapat di tafsirkan bahwa skor sikap pada matematika tersebar pada beberapa kelompok kelas interval, yaitu skor dengan persentase tertinggi terdapat pada kelas interval 50-52 sebesar $27 \%$. Sedangkan skor dengan persentase terendah terdapat pada kelas interval 59-61 dengan persentase sebesar $1 \%$. Secara umum skor variabel sikap pada matematika ini lebih banyak berkumpul pada nilai lebih dari 49 .

Selanjutnya sebelum datadata tersebut dilakukan analisis uji statistik, terlebih dahulu dilakukan beberapa uji persyaratan analisis, yang meliputi: uji normalitas, uji signifikansi dan uji koefesien regresi, serta pengujian koefesien jalur. Dari hasil perhitungan analisis menunjukkan bahwa semua sampel yang diambil berasal dari populasi berdistribusi normal. Untuk uji signifikansi dan linieritas model persamaan regresi, diperoleh hasil bahwa; model persamaan regresi kemampuan memecahkan masalah matematika $\left(\mathrm{X}_{3}\right)$ atas regulasi diri $\left(\mathrm{X}_{1}\right)$ membentuk garis linier; model persamaan regresi kemampuan memecahkan masalah matematika $\left(\mathrm{X}_{3}\right)$ atas sikap pada matematika $\left(\mathrm{X}_{2}\right)$ membentuk garis linier; dan model persamaan regresi sikap pada matematika $\left(\mathrm{X}_{2}\right)$ atas regulasi diri $\left(X_{1}\right)$ juga membentuk garis linier. 
JURNAL PENDIDIKAN USIA DINI

Volume 10 Edisi 1, April 2016

Pengujian Hipotesis

Secara umum hasil pengujian keseluruhan dapat dirangkum dalam

tabel berikut:

hipotesis penelitian secara

Tabel 1. Rekapitulasi Hasil Pengujian Hipotesis

\begin{tabular}{ccccc}
\hline Hipotesis & $\begin{array}{c}\text { Koefisien } \\
\text { Jalur }\end{array}$ & $\mathbf{T}_{\text {hitung }}$ & $\begin{array}{c}\mathbf{T}_{\text {tabel }} \\
(\alpha=0,01)\end{array}$ & Kesimpulan \\
\hline $\begin{array}{c}\text { Regulasi diri berpengaruh } \\
\text { langsung positif terhadap } \\
\text { kemampuan memecahkan } \\
\text { masalah matematika }\end{array}$ & $p_{31}=0,321$ & 3,562 & 2,36 & $\begin{array}{c}\text { Berpengaruh } \\
\text { langsung positif }\end{array}$ \\
\hline $\begin{array}{c}\text { Sikap pada matematika } \\
\text { berpengaruh langsung positif } \\
\text { terhadap kemampuan } \\
\text { memecahkan masalah } \\
\text { matematika }\end{array}$ & $p_{32}=0,384$ & 4,256 & 2,36 & $\begin{array}{c}\text { Berpengaruh } \\
\text { langsung positif }\end{array}$ \\
\hline $\begin{array}{c}\text { Regulasi diri berpengaruh } \\
\text { langsung positif terhadap sikap } \\
\text { pada matematika }\end{array}$ & $p_{21}=0,324$ & 3,308 & 2,36 & $\begin{array}{c}\text { Berpengaruh } \\
\text { langsung positif }\end{array}$ \\
\hline
\end{tabular}

Berdasarkan tabel hasil nilai $t_{\text {hitung }}(3,562)>t_{\text {tabel }}$

pengujian hipotesis di atas, maka

analisis hasil penelitian dan

pembahasan dapat di jelaskan sebagai

berikut:

Regulasi diri berpengaruh langsung

positif terhadap kemampuan

memecahkan masalah matematika

Hasil pengujian hipotesis

pertama dapat disimpulkan bahwa

regulasi diri berpengaruh langsung

positif terhadap kemampuan

memecahkan masalah matematika.

Koefisien jalur regulasi diri terhadap

kemampuan memecahkan masalah

matematika diperoleh nilai $p_{31}$ sebesar

0,321 dan uji signifikansi diperoleh sehingga koefisien jalur regulasi diri terhadap kemampuan memecahkan

masalah matematika adalah signifikan.

Hasil ini memberikan penjelasan bahwa semakin baik regulasi diri siswa maka ikut berdampak pada semakin meningkatnya kemampuan mereka dalam menyelesaikan masalahmasalah matematika. Hal ini di karenakan regulasi diri yang baik akan membuat siswa mampu mengelola perasaan dan emosinya dengan baik pula, sehingga dengan perasaaan yang terkendali diharapkan menjadi sebuah 
Pengaruh Regulasi ...

Elfiadi

tenaga pendorong untuk memecahkan suatu masalah. Hal ini sebagaimana hasil penelitian Zimmerman (2011:448-473), bahwa "to be successful in homework completion, learners need to be self-regulated by setting homework goals, selecting appropriate learning strategies, maintaining motivation, monitoring progress, and evaluating homework outcomes and a positive relationship between homework and a range of self-regulation skills exists that facilitates academic achievement". Hasil penelitian ini menunjukkan bahwa siswa yang terlibat dalam pengaturan diri cenderung menjadi individu dengan penyelesaian tugas yang lebih baik dan berprestasi secara akademik. Hal ini diperkuat juga dengan pendapat Ormrod (2008:39) bahwa "siswa yang mengatur diri biasanya memiliki keyakinan yang tinggi akan kemampuan mereka menyelesaikan suatu tugas belajar dengan sukses". Sebaliknya, semakin berkurang regulasi diri siswa akan semakin berkurang pula kemampuannya dalam melakukan pemecahan masalah matematika.

Sikap pada matematika berpengaruh langsung positif terhadap kemampuan memecahkan masalah matematika

Hasil pengujian hipotesis kedua dapat disimpulkan bahwa sikap pada matematika berpengaruh langsung positif terhadap kemampuan memecahkan masalah matematika. Koefisien jalur sikap pada matematika terhadap kemampuan memecahkan masalah matematika diperoleh nilai $p_{32}$ sebesar 0,384 dan uji signifikansi diperoleh nilai $t_{\text {hitung }}(4,256)>t_{\text {tabel }}$ (2,36) sehingga koefisien jalur regulasi diri terhadap kemampuan memecahkan masalah matematika adalah signifikan.

Dari hasil pengujian hipotesis kedua memberikan penjelasan bahwa meningkatnya sikap positif siswa pada pelajaran matematika akan mengakibatkan peningkatan juga kemampuan siswa dalam memecahkan masalah matematika. Siswa yang memiliki sikap positif terhadap matematika akan menganggap masalah sebagai suatu tantangan yang harus dihadapi sehingga mereka akan berusaha 
JURNAL PENDIDIKAN USIA DINI

Volume 10 Edisi 1, April 2016

semaksimal mungkin untuk menyelesaikan tantangan tersebut. Hal ini sebagaimana hasil penelitian Juter (2005:91-110), bahwa "students with positive attitudes perform better in solving problems" sikap positif siswa pada matematika mempengaruhi kemampuan siswa untuk memecahkan masalah matematika dengan sukses". Sehingga terbentuknya sikap positif siswa terhadap matematika merupakan pertanda awal yang baik bagi keberhasilan belajar siswa, begitu juga sebaliknya, sikap negatif siswa pada matematika merupakan awal ketidakberhasilan proses belajar dan mengajar matematika.

\section{Regulasi diri berpengaruh langsung positif terhadap sikap pada matematika}

Hasil pengujian hipotesis pertama dapat disimpulkan bahwa regulasi diri berpengaruh langsung positif terhadap sikap pada matematika. Koefisien jalur regulasi diri terhadap sikap pada matematika diperoleh nila $p_{21}$ sebesar 0,324 dan perhitungan uji signifikansi diperoleh nilai $t_{\text {hitung }}(3,308)>t_{\text {tabel }}(2,36)$ sehingga koefisien jalur regulasi diri terhadap kemampuan memecahkan masalah matematika dikatakan signifikan.

Berdasarkan hasil hipotesis ketiga ini memberikan penjelasan bahwa meningkatnya kemampuan regulasi diri siswa akan mengakibatkan peningkatan dan perubahan pada semakin positifnya sikap siswa terhadap pelajaran matematika. Siswa yang memilki regulasi yang baik akan mampu mengatur dan mengelola emosinya dengan baik pula sehingga dapat mendorong terciptanya sikap positif terhadap pembelajaran. Hal ini sebagaimana pendapat Boekaerts (2005:296) bahwa "students with good self regulation achieve higher in school, have a more positive attitude towards learning, show a higher trust in their abilities, and have more efficient learning and motivational strategies" siswa dengan regulasi diriyang baik mencapai lebih tinggi di sekolah, memiliki sikap yang lebih positif terhadap pembelajaran, menunjukkan kepercayaan yang lebih tinggi dalam kemampuan mereka, dan memiliki belajar lebih efisien dan strategi motivasi. Sebaliknya semakin berkurang regulasi diri siswa akan 
Pengaruh Regulasi ...

Elfiadi

semakin negatif pula sikap siswa pada matematika.

Dari hasil pengolahan dan analisis data hasil penelitian dapat disimpulkan bahwa: (1) terdapat pengaruh langsung positif regulasi diri terhadap kemampuan memecahkan masalah matematika. Hal ini berarti bahwa regulasi diri yang baik pada siswa kelas III SDN Kota Juang Bireuen-Aceh dapat mengakibatkan peningkatan kemampuannya memecahkan masalah matematika. Implikasinya adalah kemampuan siswa dalam memecahkan masalah matematika dapat ditingkatkan dengan regulasi diri yang baik; (2) Terdapat pengaruh langsung positif sikap pada matematika terhadap kemampuan memecahkan masalah matematika. Hal ini berarti bahwa sikap positif siswa kelas III SDN Kota Juang Bireuen-Aceh pada matematika juga dapat mengakibatkan peningkatan kemampuan memecahkan masalah matematika. Implikasinya adalah kemampuan siswa dalam memecahkan masalah matematika dapat ditingkatkan dengan memperbaiki sikap mereka pada matematika; (3) Terdapat pengaruh langsung positif regulasi diri terhadap sikap pada matematika. Hal ini berarti bahwa regulasi diri yang baik siswa kelas III SDN Kota Juang Bireuen-Aceh dapat mengakibatkan peningkatan atau perubahan sikap positif mereka pada matematika. Implikasinya sikap siswa pada matematika dapat di ubah dengan regulasi diri yang baik.

\section{SIMPULAN}

Penelitian ini diharapkan dapat memberikan kontribusi yang baik bagi pendidik/guru dalam rangka meningkatkan kemampuan pemecahan masalah matematika siswa. Untuk itu, peneliti menyarankan sebagai berikut: (1) Guru/pendidik diharapkan dapat membangun kecintaan siswa pada pelajaran matematika sedini mungkin agar diharapkan dapat timbulnya sikap positif siswa terhadap matematika; (2) Guru dan orang tua diharapkan dapat memberikan pengasuhan yang optimal bagi anaknya untuk melatih dan membiasakan anak untuk mampu meregulasi dirinya dengan baik, misalnya, disiplin waktu dalam belajar. 
JURNAL PENDIDIKAN USIA DINI

Volume 10 Edisi 1, April 2016

\section{DAFTAR PUSTAKA}

Aiken, Ewis R. 1994. Psychological Testing and Assessment. USA: Library of Congres.

Ajzen, Icek. 2005. Attitude, Personality And Behavior. New York: University Press.

Baumiester, dkk. 2013. Hand Book of Self Regulation: Reseach, Theory and Aplication. New York: The Guilford Press.

Buekaerts, Manique at all. 2005. Handbook of Self Regulation. USA: Elsevier Academic Press.

Carlson. 2000. Psychology Third Edition. New York: Allyn and Bacon.

Feldman, Papalia Olds. 2009. Human

Development.

Jakarta:

Salemba Humanika.

Groves, Linda at all. 2006. Self-

Regulation A Cornerstone of Early

Childhood

Development. Beyond the Journal: Young Children on the Web July

Juter, Kristina. Students' Attitudes to Mathematics and Performance in Limits of Functions. Mathematics Education Research Journal. Vol. 17 No. 2, 91-110.

Kaazantzis, Nikolaos at all. 2010. Cognitif and Behavior Theories in Clinical Practies. New York: The Guilford Press.

Kadir. 2010. Statiska: Untuk Penelitian Ilmu-Ilmu Sosial. Jakarta: Rosemata Sampurna.

Littlejohn, Stephen W. 2001.

Theories of Human
Communication. New York:

Wadsworth.

Ormrod, Jeanne Ellis. 2008. Psikologi Pendidikan: Membantu Siswa Tumbuh dan Berkembang Jilid 2. Jakarta: Erlangga.

Sandra M. Linder dkk, 2011. Stegelin Mathematics in Early Childhood: Research-Based Rationale and Practical Strategies, Early Childhood Educ Journal, DOI 10.1007-6.

Santrock, John W. 2008. Psikologi Pendidikan (edisi kedua). Jakarta: Kencana.

Santrock, John W. 2006. Educational Psychology second edition. New York: Mc Graw Hill.

Winne, Philip H. 1997. Experimenting to Bootstrap Self-Regulated Learning: Journal of Educational Psychology.the American Psychological Association.

Woolfolk. Anita. 2009. Educational Psychology: Active Learning Edition. Yogyakarta: Pustaka Belajar.

Zimmerman,et al. 2011. Meaningful and Maladaptive Homework Practices: The Role of SelfEfficacy and Self-Regulation, Journal of Advanced Academics, Vol. 22 (3).

2014.http://edisicetak.joglosemar.co/ berita/nilai-matematikaindonesia-terendah-di-dunia112638.html(diakses 1 November 2014)

http://news.okezone.com/read/2013/0 1/08/373/743021/large (diakses 1

November 2014) 